\section{BRAZIULIAN JOURNAL}

OF MEDICAL AND BIOLOGICAL RLSH.ARCH

www.bjournal.com.br
ISSN 0100-879X

Volume 43 (01) 1-123 January 2010

BIOMEDICAL SCIENCES

AND

CLINICAL INVESTIGATION

Braz J Med Biol Res, J anuary 2010, Volume 43(1) 52-56

Role of $11 \beta$-hydroxysteroid dehydrogenase 2 renal activity in potassium homeostasis in rats with chronic renal failure

N.L. Yeyati, M.E. Altuna, M.C. Damasco and M.A. Mac Laughlin

The Brazilian Journal of Medical and Biological Research is partially financed by
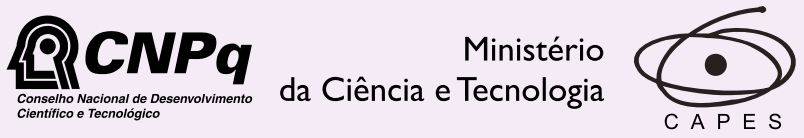

Ministério da Educação

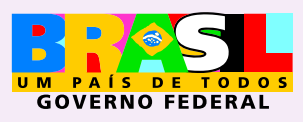

Institutional Sponsors 


\title{
Role of $11 \beta$-hydroxysteroid dehydrogenase 2 renal activity in potassium homeostasis in rats with chronic renal failure
}

\author{
N.L. Yeyati ${ }^{1}$, M.E. Altuna ${ }^{2}$, M.C. Damasco ${ }^{2}$ and M.A. Mac Laughlin ${ }^{1}$ \\ 1Departamento de Fisiología y Biofísica, Facultad de Medicina, \\ Universidad de Buenos Aires, CONICET, Buenos Aires, Argentina \\ 2Departamento de Química Biológica, Facultad de Ciencias Exactas y Naturales, \\ Universidad de Buenos Aires, CONICET, Buenos Aires, Argentina
}

\begin{abstract}
Aldosterone concentrations vary in advanced chronic renal failure (CRF). The isozyme $11 \beta$-hydroxysteroid dehydrogenase 2 $(11 \beta-H S D 2)$, which confers aldosterone specificity for mineralocorticoid receptors in distal tubules and collecting ducts, has been reported to be decreased or normal in patients with renal diseases. Our objective was to determine the role of aldosterone and $11 \beta-H S D 2$ renal microsome activity, normalized for glomerular filtration rate (GFR), in maintaining $\mathrm{K}^{+}$homeostasis in $5 / 6$ nephrectomized rats. Male Wistar rats weighing 180-220 $\mathrm{g}$ at the beginning of the study were used. Rats with experimental CRF obtained by $5 / 6$ nephrectomy $(N=9)$ and sham rats $(N=10)$ were maintained for 4 months. Systolic blood pressure and plasma creatinine (Pcr) concentration were measured at the end of the experiment. Sodium and potassium excretion and GFR were evaluated before and after spironolactone administration $\left(10 \mathrm{mg} \cdot \mathrm{kg}^{-1} \cdot \mathrm{day}^{-1}\right.$ for 7 days) and $11 \beta$-HSD2 activity on renal microsomes was determined. Systolic blood pressure (means \pm SEM; Sham $=105 \pm 8$ and CRF = $149 \pm 10 \mathrm{mmHg}$ ) and Pcr (Sham $=0.42 \pm 0.03$ and CRF $=2.53 \pm 0.26 \mathrm{mg} / \mathrm{dL})$ were higher $(P<0.05)$ while GFR (Sham $=1.46 \pm 0.26$ and $\mathrm{CRF}=0.61$ $\pm 0.06 \mathrm{~mL} / \mathrm{min}$ ) was lower $(\mathrm{P}<0.05)$ in $\mathrm{CRF}$, and plasma aldosterone (Pald) was the same in the two groups. Urinary sodium and potassium excretion was similar in the two groups under basal conditions but, after spironolactone treatment, only potassium excretion was decreased in CRF rats (sham $=0.95 \pm 0.090$ (before) vs $0.89 \pm 0.09 \mu \mathrm{Eq} / \mathrm{min}$ (after) and CRF $=1.05 \pm$ 0.05 (before) vs $0.37 \pm 0.07 \mu \mathrm{Eq} / \mathrm{min}$ (after); $\mathrm{P}<0.05$ ). $11 \beta$-HSD2 activity on renal microsomes was lower in $\mathrm{CRF}$ rats (sham $=$ $0.807 \pm 0.09$ and CRF $=0.217 \pm 0.07 \mathrm{nmol} \cdot \mathrm{min}^{-1} \cdot \mathrm{mg}$ protein ${ }^{-1} ; \mathrm{P}<0.05$ ), although when normalized for $\mathrm{mL}$ GFR it was similar in both groups. We conclude that $\mathrm{K}^{+}$homeostasis is maintained during CRF development despite normal Pald levels. This adaptation may be mediated by renal $11 \beta-H S D 2$ activity, which, when normalized for GFR, became similar to that of control rats, suggesting that mineralocorticoid receptors maintain their aldosterone selectivity.
\end{abstract}

Key words: Aldosterone; 5/6 Nephrectomy; 11ß-HSD2; Potassium excretion

\section{Introduction}

Potassium homeostasis is maintained up to the advanced stage of chronic renal failure (CRF) by increased fractional potassium excretion, while the glomerular filtration rate (GFR) is decreased (1-4). Although aldosterone is the key factor involved in $\mathrm{K}^{+}$homeostasis, its plasma concentration in CRF varies. Both increased and normal values (5-8) have been reported. The specific renal effect of aldosterone depends on the cytoplasmic access of aldosterone to its specific mineralocorticoid receptors (9-12). These receptors bind both mineralo- and glucocorticoids with high affinity (13-16). The isozyme $11 \beta$-hydroxysteroid dehydrogenase
2 (11ß-HSD2) converts cortisol to cortisone (13-16), consequently preventing mineralocorticoid receptor stimulation by cortisol and conferring specificity for aldosterone to this receptor. The isozyme is predominantly found in target aldosterone tissues: distal convoluted tubules, cortical collecting ducts (17) and colon (18). Impaired renal 11 $\beta-H S D 2$ activity has been described in patients with hypoxia (19) or impaired renal function (20) and in nephrotic rats (21), leading to sodium retention, hypokalemia and salt-dependent hypertension. However, an important consideration has not been discussed in these studies. Since GFR, an index

Correspondence: M.A. Mac Laughlin, Departamento de Fisiología, Facultad de Medicina, Universidad de Buenos Aires, calle Paraguay, 2155, 6th, 1421 Buenos Aires, Argentina. E-mail: mmaclaughlin@fmed.uba.ar

Received December 5, 2008. Accepted November 26, 2009. Available online December 18, 2009. Published January 11, 2010. 
of nephron mass, is markedly reduced in CRF, this should be taken into account when renal $11 \beta-H S D 2$ activity is evaluated.

The aim of the present investigation was to study the role of aldosterone and $11 \beta-H S D 2$ renal microsome activity in maintaining $\mathrm{K}^{+}$homeostasis in $5 / 6$ nephrectomized rats. To address this question we evaluated renal function, systolic blood pressure (SBP), plasma aldosterone, and $11 \beta$-HSD2 renal microsome activity in $5 / 6$ nephrectomized and sham rats.

\section{Material and Methods}

\section{Animals}

Animals were used in compliance with the animal Research Guidelines of the American Heart Association (www.americanheart.org).

Male Wistar rats weighing 180 to $220 \mathrm{~g}$ were used. The animals had free access to Purina Rodent Laboratory chow and water throughout the experiment. This standard diet contains $282 \mathrm{mmol} / \mathrm{kg} \mathrm{K}^{+}$, and $174 \mathrm{mmol} / \mathrm{kg} \mathrm{Na}^{+}$. Experimental renal insufficiency was induced in rats $(\mathrm{N}=9)$ according to the technique of Morrison (22). The two poles of the left kidney were removed and the right kidney was excised one week later. Sham rats $(N=10)$ submitted to laparotomy and manipulation of the renal pedicles were used as controls.

\section{Experimental protocol}

Rats were housed in a humidity- and temperaturecontrolled environment with an automatic light/dark cycle of $12: 12 \mathrm{~h}$ and studied for 4 months starting at the time of right kidney nephrectomy.

Systolic blood pressure and plasma creatinine concentration were measured every month. At the end of this period, rats were adapted to metabolic cages during a period of 4 days. Subsequently, a blood sample and 24-h urine were obtained. Urinary flow, GFR, obtained by creatinine clearance, and sodium and potassium excretion were determined. Spironolactone, an aldosterone antagonist analogue extensively used in experimental studies on rats (23-25), was administered by gavage $(10 \mathrm{mg} / \mathrm{kg}$ body weight) daily for 7 days. Next, rats were returned to metabolic cages and the same experimental procedure was performed. The experimental group contained 9 rats and the sham-operated group 10 rats.

\section{Measurement of $11 \beta-H S D 2$ activity in renal microsomes}

Rats were anesthetized with ether and kidneys were perfused with $0.9 \% \mathrm{NaCl}$, excised, decapsulated, and sliced. The slices were resuspended in $0.1 \mathrm{M}$ sodium phosphate buffer containing $1.5 \mathrm{mM} \mathrm{MgCl}_{2}$, pH 7.4 (MG buffer; $25 \mathrm{~mL}$ MG buffer/g tissue) and homogenized with a Potter Teflon homogenizer. Homogenates were centrifuged at 12,000 g for $30 \mathrm{~min}$. The supernatant was then centrifuged at 105,000 $g$ for $60 \mathrm{~min}$ and the microsome fraction thus obtained was resuspended in MG buffer. Total protein was determined by the method of Bradford (26).

Isozyme activity was determined by measuring the conversion rate of ${ }^{3} \mathrm{H}$-corticosterone to ${ }^{3} \mathrm{H}$-11-dehydrocorticosterone (27). Microsomal suspensions containing $250 \mu \mathrm{g}$ protein/mL were incubated in $250 \mu \mathrm{L}$ MG buffer containing $14 \mathrm{nM}^{3} \mathrm{H}$-corticosterone and $400 \mu \mathrm{M} \mathrm{NAD}^{+}$for $10 \mathrm{~min}$ at $37^{\circ} \mathrm{C}$ and the reaction was stopped by the addition of ethyl acetate. Steroids were extracted, and then separated by thin layer chromatography using chloroform-ethanol (92:8). The ${ }^{3} \mathrm{H}$-corticosterone and ${ }^{3} \mathrm{H}$-11 $\beta$-dehydrocorticosterone were eluted and radioactivity was counted. Enzyme specific isozyme activity is reported as $\mathrm{nmol} \cdot \mathrm{min}^{-1} \cdot \mathrm{mg} \mathrm{protein}^{-1}$.

\section{Analytical methods}

Aldosterone was measured in blood samples by radioimmunoassay, SBP was determined by tail plethysmography in awake rats (28), $\mathrm{Na}^{+}$and $\mathrm{K}^{+}$concentrations were determined in urine samples by flame photometry, and plasma and urinary creatinine were determined by a modified Jaffe method, which prevents nonspecific reaction (29).

\section{Statistical analysis}

Data are reported as means \pm SEM. To test for statistically significant differences $(\mathrm{P}<0.05)$, the Student $t$-test for paired or unpaired data, as appropriate, was performed.

\section{Results}

Rats with 5/6 nephrectomy developed a significant deterioration of renal function, as shown in Table 1. In fact, after 4 months, at the end of the experiments, plasma creatinine concentration and the SBP were higher $(P<0.05)$ and GFR was significantly lower in CRF rats. The validity of the use of creatinine clearance to evaluate GFR in Wistar rats was demonstrated (30). Although CRF effectively developed

Table 1. Plasma creatinine, systolic blood pressure, glomerular filtration rate, and plasma aldosterone levels of sham and chronic renal failure rats.

\begin{tabular}{lcc}
\hline & Sham $(\mathrm{N}=10)$ & CRF $(\mathrm{N}=9)$ \\
\hline Pcr $(\mathrm{mg} / \mathrm{dL})$ & $0.42 \pm 0.03$ & $2.53 \pm 0.26^{*}$ \\
SBP $(\mathrm{mmHg})$ & $105 \pm 8$ & $149 \pm 10^{*}$ \\
GFR $(\mathrm{mL} / \mathrm{min})$ & $1.46 \pm 0.26$ & $0.61 \pm 0.06^{*}$ \\
Pald $(\mathrm{pg} / \mathrm{mL})$ & $1,746 \pm 191$ & $1,615 \pm 113$ \\
\hline
\end{tabular}

Data are reported as means \pm SEM. Measurements were made 4 months after 5/6 nephrectomy. CRF = chronic renal failure; Pcr = plasma creatinine; $\mathrm{SBP}=$ systolic blood pressure; GFR = glomerular filtration rate; Pald $=$ plasma aldosterone. ${ }^{*} \mathrm{P}<0.05$ vs sham (Student $t$-test for unpaired data). 
after $5 / 6$ nephrectomy, plasma $\mathrm{K}^{+}$concentration (Table 2) continued to be normal.

Although urinary sodium and potassium excretion did not differ in either group under basal conditions (Figure 1), fractional $\mathrm{Na}^{+}$excretion [sham: $0.19 \pm 0.02 \%(\mathrm{~N}=10)$, CRF: $0.45 \pm 0.09 \%(\mathrm{~N}=9)$ ], and fractional $\mathrm{K}^{+}$excretion [sham: $13.25 \pm 1.26 \%(\mathrm{~N}=10), \mathrm{CRF}: 37.25 \pm 3.50 \%$ ( $\mathrm{N}=$ 9)] were significantly higher $(P<0.01)$ in $5 / 6$ nephrectomized rats. Thus, a tubular adaptation allowing the remaining nephrons to preserve the electrolyte balance must have been developed in the nephrectomized group. In contrast, no difference was found in plasma aldosterone between sham and CRF rats (Table 1), although, after treatment with spironolactone, the two groups responded in different ways (Figure 1). Sodium excretion was not modified in either group and $\mathrm{K}^{+}$excretion did not change in sham rats but was substantially decreased in CRF rats $(P<0.05)$. Thus, plasma potassium concentration increased significantly only in CRF rats treated with spironolactone, as shown in Table 2. This specific effect of spironolactone suggests an adaptive response of mineralocorticoid receptors in the distal nephrons of CRF rats. When $11 \beta-H S D 2$ renal microsome activity was measured, a lower value was obtained for the CRF group ( $P<0.05$; Figure 2). However, when $11 \beta-H S D 2$ activity was normalized for $\mathrm{mL}$ GFR, an index of remnant nephron mass, there was no difference between groups.
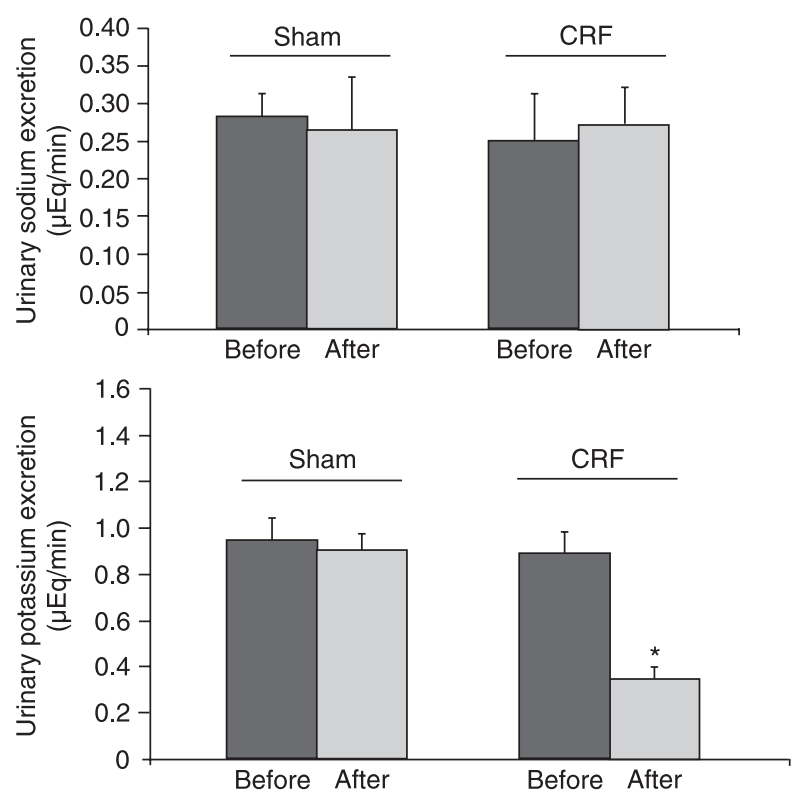

Figure 1. Urinary sodium and potassium excretion of sham and chronic renal failure (CRF) rats before and after spironolactone treatment $\left(10 \mathrm{mg} \cdot \mathrm{kg}^{-1} \cdot \mathrm{day}^{-1}\right.$ for 1 week). Measurements were made 4 months after $5 / 6$ nephrectomy or sham operation. Data are reported as means \pm SEM. ${ }^{*} \mathrm{P}<0.05$ vs before treatment (Student $t$-test for paired data).

\section{Discussion}

In the present study, plasma $\mathrm{Na}^{+}$and $\mathrm{K}^{+}$concentrations were similar in sham and CRF rats, showing that the electrolyte balance was preserved throughout the 4-month study. The compensation of renal function in order to maintain electrolyte homeostasis while renal disease is developing has been well documented $(31,32)$. The "intact nephron hypothesis" (31) considers a special mechanism in remnant nephrons that elevates GFR and enlarges the tubule. This specific adaptation facilitates $\mathrm{Na}^{+}, \mathrm{K}^{+}$and water handling $(33,34)$. On this basis, we demonstrated that fractional $\mathrm{Na}^{+}$and $\mathrm{K}^{+}$excretion was significantly higher in $5 / 6$ nephrectomized rats. We emphasize the low relationship of $\mathrm{Na}^{+}$and $\mathrm{K}^{+}$excretion in sham rats, of the order of 1 to 4 , when the expected one was $2 / 1$ (35). It should be pointed out that our rats were fed a standard commercial Purina Rodent Laboratory diet, which in comparison with the occidental human diet (36) contains high $\mathrm{K}^{+}$and low $\mathrm{Na}^{+}$(see Methods).

Plasma aldosterone levels were the same in the two

Table 2. Effect of spironolactone on plasma potassium of sham and chronic renal failure rats.

Plasma potassium (mEq/L)

\begin{tabular}{lcc}
\hline & \multicolumn{2}{c}{ Plasma potassium $(\mathrm{mEq} / \mathrm{L})$} \\
\cline { 2 - 3 } & Before spironolactone & After spironolactone \\
\hline Sham $(\mathrm{N}=10)$ & $4.77 \pm 0.26$ & $5.32 \pm 0.25$ \\
CRF $(\mathrm{N}=9)$ & $4.89 \pm 0.43$ & $5.91 \pm 0.31^{*}$ \\
\hline
\end{tabular}

Data are reported as means \pm SEM. Measurements were made 4 months after 5/6 nephrectomy or sham operation. CRF = chronic renal failure. Spironolactone was administered by gavage $\left(10 \mathrm{mg} \cdot \mathrm{kg}^{-1} \cdot \mathrm{day}^{-1}\right.$ for 1 week). ${ }^{*} \mathrm{P}<0.05$ vs before (Student $t$-test for paired data).
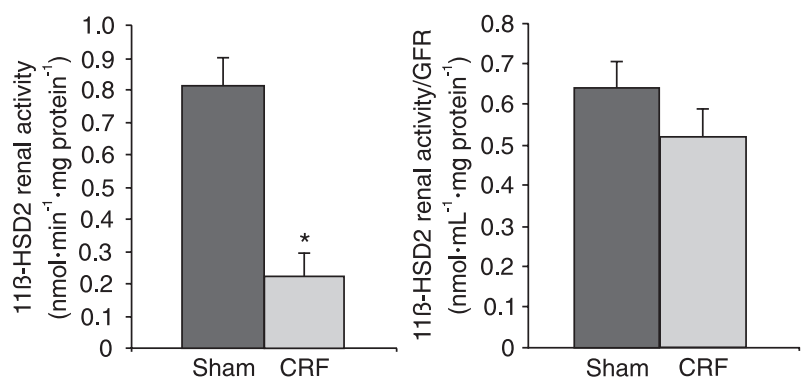

Figure 2. Renal microsome 11ß-hydroxysteroid dehydrogenase $2(11 \beta-H S D 2)$ activity and $11 \beta$-HSD2 activity normalized for $\mathrm{mL}$ glomerular filtration rate (GFR) of sham and chronic renal failure (CRF) rats. Measurements were made 4 months after 5/6 nephrectomy or sham operation. Data are reported as means \pm SEM. ${ }^{*} \mathrm{P}<0.05$ vs sham (Student $t$-test for unpaired data). 
groups but spironolactone treatment only modified $\mathrm{K}^{+}$ excretion in 5/6 nephrectomized rats (Figure 1). We may speculate that during chronic renal failure, mineralocorticoid receptors develop a higher aldosterone sensitivity. This could be an important adaptive mechanism, which allows remnant tubular nephrons to handle the $\mathrm{K}^{+}$overload.

As pointed out above, the apparent difference in the effect of spironolactone on potassium and sodium excretion can be explained by the effect of the low $\mathrm{Na}^{+}$and high $\mathrm{K}^{+}$ content of the Purina rat diet when compared to the occidental human diet, which have more sodium than potassium (36). Accordingly, Malnic et al. (37) found that, in spite of the low sodium content of the diet, the distal nephron handling of potassium might not be affected.

The $11 \beta-H S D 2$ renal microsome activity was significantly lower in our CRF animals. Impaired activity of this isozyme has been demonstrated in hypoxia (19) and in renal disease $(20,21)$, syndromes that develop with abnormal handling of potassium and sodium and high blood pressure. These observations led us to hypothesize that the decreased $11 \beta-H S D 2$ may improve the access of glucocorticoids to mineralocorticoid receptors, leading to hypertension and $\mathrm{Na}^{+}$retention. However, contradictory results have been reported by others. Bistrup et al. (21), working with a puromycin aminonucleoside model of nephrotic syndrome, have shown that, although renal $11 \beta-H S D 2$ was down-regulated, total protein expression was unchanged. Furthermore, working with aging WAG/rij rats, a strain without increased blood pressure or that does not develop kidney disease with age,

\section{References}

1. Gennari FJ, Segal AS. Hyperkalemia: An adaptive response in chronic renal insufficiency. Kidney Int 2002; 62: 1-9.

2. Musso CG, Miguel R, Algranati L, Farias ER. Renal potassium excretion: comparison between chronic renal disease patients and old people. Int Urol Nephrol 2005; 37: 167-170.

3. Bourgoignie JJ, Gavellas G, Van Putten V, Berl T. Potassium-aldosterone response in dogs with chronic renal insufficiency. Miner Electrolyte Metab 1985; 11: 150-154.

4. Musso CG. Potassium metabolism in patients with chronic kidney disease (CKD), Part I: patients not on dialysis (stages 3-4). Int Urol Nephrol 2004; 36: 465-468.

5. Hene RJ, Boer P, Koomans HA, Mees EJ. Plasma aldosterone concentrations in chronic renal disease. Kidney Int 1982; 21: 98-101.

6. Navaneethan SD, Nigwekar SU, Sehgal AR, Strippoli GF. Aldosterone antagonists for preventing the progression of chronic kidney disease. Cochrane Database Syst Rev 2009; CD007004.

7. Hene RJ, Koomans HA, Boer P, Dorhout Mees EJ. Effect of high-dose aldosterone infusions on renal electrolyte excretion in patients with renal insufficiency. Am J Nephrol 1987; 7: 33-37.

8. Berl T, Katz FH, Henrich WL, de Torrente A, Schrier RW. Role of aldosterone in the control of sodium excretion in patients with advanced chronic renal failure. Kidney Int 1978;
Audigè et al. (38) did not obtain any evidence suggesting enhanced kidney gene expression or activity of $11 \beta-H S D 2$. They concluded that endogenous $11 \beta-H S D 2$ is able to cope with the increased corticosterone concentrations characteristic of the aging process. Yet, the progressive loss of nephron mass associated with advanced age $(39,40)$, which must impair GFR, was not taken into account by Audigè et al. (38). In the present investigation, GFR was markedly reduced as a consequence of a $5 / 6$ reduction in the renal mass (Table 1). When we normalized $11 \beta$-HSD2 activity for $\mathrm{mL}$ GFR, we did not observe a difference between sham and CRF rats (Figure 2). Thus, when reduction of nephron mass is considered, $11 \beta-H S D 2$ activity appears to be sufficient to maintain mineralocorticoid receptor specificity in the remnant nephrons.

In conclusion, the present study demonstrates one of the mechanisms that may contribute to $\mathrm{K}^{+}$homeostasis up to the advanced stage of renal failure. Despite normal aldosterone plasma level, plasma $\mathrm{K}^{+}$concentration remained normal. The isozyme $11 \beta-H S D 2$ can, when taking the reduced nephron mass into account, be able to preserve $\mathrm{K}^{+}$balance by protecting mineralocorticoid receptors.

\section{Acknowledgments}

We thank Miss Alcira Gallego, School of Medicine, UBA, for efficient technical assistance. Research supported by CONICET (PIP-5206/05).
14: 228-235.

9. Todd-Turla KM, Schnermann J, Fejes-Toth G, Naray-FejesToth A, Smart A, Killen PD, et al. Distribution of mineralocorticoid and glucocorticoid receptor mRNA along the nephron. Am J Physiol 1993; 264: F781-F791.

10. Arriza JL, Weinberger C, Cerelli G, Glaser TM, Handelin $\mathrm{BL}$, Housman DE, et al. Cloning of human mineralocorticoid receptor complementary DNA: structural and functional kinship with the glucocorticoid receptor. Science 1987; 237: 268-275.

11. Escher G, Frey BM, Frey FJ. 11 beta-hydroxysteroid dehydrogenase - why is it important for the nephrologist? Nephrol Dial Transplant 1995; 10: 1506-1509.

12. Funder JW, Pearce PT, Smith R, Smith AI. Mineralocorticoid action: target tissue specificity is enzyme, not receptor, mediated. Science 1988; 242: 583-585.

13. Zallocchi ML, Matkovic L, Calvo JC, Damasco MC. Adrenal gland involvement in the regulation of renal 11 betahydroxysteroid dehydrogenase 2. J Cell Biochem 2004; 92 : 591-602.

14. Biller KJ, Unwin RJ, Shirley DG. Distal tubular electrolyte transport during inhibition of renal 11beta-hydroxysteroid dehydrogenase. Am J Physiol Renal Physiol 2001; 280: F172-F179.

15. Morris DJ, Latif SA, Brem AS. Interactions of mineralocor- 
ticoids and glucocorticoids in epithelial target tissues revisited. Steroids 2009; 74: 1-6.

16. Vantyghem MC, Marcelli-Tourvieille S, Defrance F, Wemeau JL. [11beta-hydroxysteroid dehydrogenases. Recent advances]. Ann Endocrinol 2007; 68: 349-356.

17. Bonvalet JP, Doignon I, Blot-Chabaud M, Pradelles P, Farman N. Distribution of 11 beta-hydroxysteroid dehydrogenase along the rabbit nephron. J Clin Invest 1990; 86: 832-837.

18. Whorwood CB, Barber PC, Gregory J, Sheppard MC, Stewart PM. 11 beta-hydroxysteroid dehydrogenase and corticosteroid hormone receptors in the rat colon. Am J Physiol 1993; 264: E951-E957.

19. Heiniger CD, Kostadinova RM, Rochat MK, Serra A, Ferrari $P$, Dick $B$, et al. Hypoxia causes down-regulation of 11 betahydroxysteroid dehydrogenase type 2 by induction of Egr-1. FASEB J 2003; 17: 917-919.

20. Quinkler M, Zehnder D, Lepenies J, Petrelli MD, Moore JS, Hughes SV, et al. Expression of renal 11beta-hydroxysteroid dehydrogenase type 2 is decreased in patients with impaired renal function. Eur J Endocrinol 2005; 153: 291-299.

21. Bistrup C, Thiesson HC, Jensen BL, Skott O. Reduced activity of 11 beta-hydroxysteroid dehydrogenase type 2 is not responsible for sodium retention in nephrotic rats. Acta Physiol Scand 2005; 184: 161-169.

22. Morrison $A B$. Experimentally induced chronic renal insufficiency in the rat. Lab Invest 1962; 11: 321-332.

23. Ortiz RM, Graciano ML, Mullins JJ, Mitchell KD. Aldosterone receptor antagonism alleviates proteinuria, but not malignant hypertension, in Cyp1a1-Ren2 transgenic rats. $\mathrm{Am} \mathrm{J}$ Physiol Renal Physiol 2007; 293: F1584-F1591.

24. Juknevicius I, Segal Y, Kren S, Lee R, Hostetter TH. Effect of aldosterone on renal transforming growth factor-beta. Am J Physiol Renal Physiol 2004; 286: F1059-F1062.

25. Virdis A, Neves MF, Amiri F, Viel E, Touyz RM, Schiffrin EL. Spironolactone improves angiotensin-induced vascular changes and oxidative stress. Hypertension 2002; 40: 504510.

26. Bradford MM. A rapid and sensitive method for the quantitation of microgram quantities of protein utilizing the principle of protein-dye binding. Anal Biochem 1976; 72: 248-254.

27. Igarreta $P$, Calvo JC, Damasco MC. Activity of renal 11 betahydroxysteroid dehydrogenase 2 (11betaHSD2) in stressed animals. Life Sci 1999; 64: 2285-2290.

28. Leenen $\mathrm{FH}$, de Jong W. A solid silver clip for induction of predictable levels of renal hypertension in the rat. $J$ Appl Physiol 1971; 31: 142-144.

29. Slot C. Plasma creatinine determination. A new and specific Jaffe reaction method. Scand J Clin Lab Invest 1965; 17: 381-387.

30. Van Liew JB, Zamlauski-Tucker MJ, Feld LG. Endogenous creatinine clearance in the rat: strain variation. Life Sci 1993; 53: 1015-1021.

31. Bricker NS. On the meaning of the intact nephron hypothesis. Am J Med 1969; 46: 1-11.

32. Meyer TW, Scholey JW, Brenner BM. Nephron adaptation to renal injury. In: Brenner BM, Rector FC (Editors), The kidney. 4th edn. Philadelphia: W.B. Saunders; 1991. p 1872-1890.

33. Allison ME, Wilson CB, Gottschalk CW. Pathophysiology of experimental glomerulonephritis in rats. J Clin Invest 1974; 53: $1402-1423$.

34. Kramp RA, MacDowell M, Gottschalk CW, Oliver JR. A study by microdissection and micropuncture of the structure and the function of the kidneys and the nephrons of rats with chronic renal damage. Kidney Int 1974; 5: 147-176.

35. Levy YN, Fellet A, Arranz C, Balaszczuk AM, Adrogue HJ. Amiloride-sensitive and amiloride-insensitive kaliuresis in advanced chronic kidney disease. J Nephrol 2008; 21: 9398.

36. Frassetto L, Morris RC Jr, Sellmeyer DE, Todd K, Sebastian A. Diet, evolution and aging - the pathophysiologic effects of the post-agricultural inversion of the potassium-to-sodium and base-to-chloride ratios in the human diet. Eur $\mathrm{J}$ Nutr 2001; 40: 200-213.

37. Malnic G, Klose RM, Giebisch G. Micropuncture study of renal potassium excretion in the rat. Am J Physiol 1964; 206: 674-686.

38. Audige A, Dick B, Frey BM, Frey FJ, Corman B, Vogt B. Glucocorticoids and 11 beta-hydroxysteroid dehydrogenase type 2 gene expression in the aging kidney. Eur J Clin Invest 2002; 32: 411-420.

39. Dunnill MS, Halley W. Some observations on the quantitative anatomy of the kidney. J Pathol 1973; 110: 113-121.

40. McLachlan MS, Guthrie JC, Anderson CK, Fulker MJ. Vascular and glomerular changes in the ageing kidney. J Pathol 1977; 121: 65-78. 